\title{
Determinants of Government Expenditure on Public Flagship Projects in Kenya
}

\author{
Silas Muyela Nganyi ${ }^{1}$, Ambrose Jagongo ${ }^{2}$ \& Gerald Kalenywa Atheru ${ }^{3}$ \\ ${ }^{1} \mathrm{PhD}$ (Fellow), School of Business, Kenyatta University, Nairobi, Kenya \\ ${ }^{2}$ Chairman, Accounting and Finance, School of Business, Kenyatta University, Nairobi, Kenya \\ ${ }^{3}$ Lecturer, School of Business, Kenyatta University, Nairobi, Kenya \\ Correspondence: Silas Muyela Nganyi, School of Business, Kenyatta University, Nairobi, Kenya. E-mail: \\ silmuyela@yahoo.com
}

Received: January 10, 2019

Accepted: May 24, 2019

Online Published: May 28, 2019

doi:10.5539/ijef.v11n6p133

URL: https://doi.org/10.5539/ijef.v11n6p133

\begin{abstract}
The Kenya Vision 2030 flagship projects expected to generate rapid economic growth in the country are threatened by inadequate source of funding, financial management problems and failure to link policy, planning and expenditure budgeting. The projects continue to experience inadequacies in project appraisal and implementation time overruns. Therefore, without a clear financial framework, fiscal indiscipline, resource misallocation and inefficient use of resources will militate against achieving the Kenya Vision 2030 targets. The overall objective of this study was to evaluate determinants of government expenditure on public flagship projects in Kenya. The specific objectives were to: evaluate the influence of planning process; source of funds; and management responsibility on government expenditure on public flagship projects in Kenya. The theories reviewed in the study were public finance, budget, cost-benefit analysis and principal-agent which provided grounds for conceptual framework. The study employed descriptive research design, positivist philosophy and multiple regression model. The target population was the planned 348 flagship projects for the period 2008-2012. The unit of analysis was projects based on sample size of 96 stratified random sample while data was collected using a questionnaire. The findings showed that planning process, source of funds and management responsibility had significant positive influence in determining government expenditure on public flagship project in Kenya. The study recommended that, public entities should strengthen and improve planning process by deepening MTEF within programme-based budgeting; the National Treasury should increase resources required for financing public flagship projects by considering public-private-partnerships as a potential source; and public entities should improve, strengthen and enforce management responsibility when designing public flagship projects. The two areas suggested for further research were; impact of project characteristics on the choice of Public-Private Partnership financing model; and impact of fiscal decentralization on financing public projects in light of devolved systems of governance in Kenya.
\end{abstract}

Keywords: government expenditure, management responsibility, medium term expenditure framework, planning process, source of funds, and public flagship project

\section{Background to the Study}

According to Jin and Zou (2005), revenue and expenditure assignment theory is fundamental in determining government expenditure on public projects. The theory suggests that, a convergence of revenue and expenditure assignments is positively associated with allocative efficiency and a high economic growth rate. Jin and Zou (2005) argue that revenue and expenditure assignment can be amplified by effective fiscal decentralization procedures and objective project expenditure rationalisation while at the same its application can play a better position to allocate budgetary resources for horizontal balance, economic growth, macroeconomic stability, and investment in projects of national significance.

Shah and Hagen (2007) found out that, the effectiveness of government expenditures on public projects are hinged on planning process, project appraisal criteria applied, management responsibility and political environment for making project expenditure decision. By applying agency theory, Linder and Foss (2013) concluded that management responsibility is a significant determinant in the type of long term finance decisions. 
Linder et al (2013) noted that, employees who choose to manipulate financial results through managerial activity and that activity maximizes the return to that person rather than financial return to the organisation then there is an agency problem. Gailmard and Patty (2007) states that, the principal-agent theory has proven to be a flexible and useful approach for interpreting effects of institutional arrangements on accountability of public decision makers and public policy. The agency theory explains the relationships between public bureaucrats as agents and citizens as the stakeholders whose welfare should be maximised as a result of financial decisions taken by government (Bowie \& Norman, 2008). Ferejohn (2009) developed a pure moral hazard model of accountability in public finance that taps into key concerns about development project decisions as instruments of control and sometimes for political opportunism.

Abdulla and Maamor (2010) states that, government expenditure on public projects is an important component of public policy since it is used to realize budgetary objectives including debt management, resource allocation and averting fiscal crises. According to Abdulla and Maamor (2010), public projects are long term investment vehicles loaded with economic development agenda to carry the economy towards growth. Aruwa (2010) reiterated that, the effectiveness of public flagship project expenditures determines the level of economic growth which can be evidenced by rise in job opportunities creation and increase of citizens' income. Aruwa (2010) however, notes that, in most developing economies, misallocation, wrong prioritization, abuse and mismanagement of project funds pose a tremendous challenge for the efficiency and effectiveness of development interventions and poverty reduction. It is from this perspective that development project expenditure must be given due attention since it is a driver to economic growth of a country; it must therefore be enhanced (Abdullah \& Maamor, 2010).

According to Labonte (2010), public projects have multiple roles: as instruments of fiscal policy, to improve the net worth of government, and-particularly in the area of economic infrastructure-as vehicles for economic development. HM Treasury (2011) reiterated that in the public sector there is a vast number and diverse range of potential uses of resources and the efficient use of resources has a significant impact on the welfare of citizens. Thus, there are many appraisal criteria that can be applied in determining the public flagship projects' expenditure decisions such as internal rate of return, net present value and cost benefit analysis (Palmer, 2012). However, to apply this techniques remain a problem.

In its effort to transform the country into a modern, globally competitive, middle income country, offering a high quality of life for all citizens by the year 2030, the Government of Kenya developed the Vision 2030 (Republic of Kenya, 2008). According to European Union (2014) flagships projects are long-term; multi-disciplinary knowledge-base; have clear mission and a unifying goal; high macro-regional transformational impacts; problem oriented; well defined implementation plan; clear financing structure; creates competitive advantage for the economy; and capable of innovations for delivering substantial benefits to society. The Institute of Economic Affairs (2013) remarked that, the Kenya vision 2030 blue print is seeking to catapult Kenya into middle-income status within a generation, the roadmap proceeds on flagship projects categorized on three fronts: economic growth - the ambition is to achieve 10\% growth annually from 2012; social transformation - through the efficient delivery of and equitable access to social services; and political - deepening democratic reforms and strengthening governance systems. Consequently the Kenya Vision 2030 flagship projects are critical vehicles to achieving the vision and in promoting development in the country. However, according to Institute of Economic affairs (2013) the vision 2030 may become a mirage unless aggregate fiscal discipline, resource allocation based on strategic priorities and efficient and effective use of resources - three important standards against which to measure the public expenditure - are addressed.

World Bank (2013) observed that, government expenditure on public flagship project should attempt to have new way to analyze a problem, try to understand where the roadblocks exist to improving outcomes, and formulate strategies for system strengthening. The components of the flagship should include where funding for the project come from, pooling of funds, and how are they allocated and spent (financing); the place of various actors in the system; political support needed to bring about positive change; and how national systems reflect the country's and community's values. The first medium term plan (MTP I) of Kenyan Vision 2030 (Republic of Kenya, 2008) identified key flagship projects such as Tourism, Agriculture and Livestock; Manufacturing; Wholesale and Trade; ICT and BPOs; Employment and Job-Creation; Education; Health; Water; Gender, Vulnerable Groups and Youth; Housing; Physical Infrastructure; and Energy. The other strategies and measurers to be pursued in the first medium term period included the strengthening of the institutional framework for infrastructure development; raising the efficiency and quality of infrastructure as well as increasing the pace of implementation of infrastructure projects so that they are completed within the specified time frames. A National Spatial Plan to optimise the development and utilisation of infrastructure facilities and services was therefore to be developed. 
The total financing for the flagship projects from PPP was estimated at KShs. 250 billions. (Republic of Kenya, 2011). The operationalisation of the PPP policy was to facilitate private sector participation in complementing public sector interventions. Some of the projects have faced financial management problems (for transparency and accountability), poor public expenditure decisions, underutilization of development funds and inadequate budgetary provisions (World Bank, 2013). According to Kenya Institute for Public Policy Research and Analysis (2013), the flagship projects have not yielded desired results such that, the overall poverty levels increased from 48.8 per cent in 2007 to 49.8 per cent in 2012 , and the number of poor people in the country estimated at 18.2 million in 2007 soared to 20.1 million in 2010. Though, the flagship projects in the industrial sector were planned to stimulate growth rate of 12.4 percent, the actual growth rate stood at 3.3 percent in 2011. In the same vein, only 2.2 percent of a new terminal container covering an area of 100 hectares at the port of Mombasa was completed, 5000 acres of land acquired for establishment of Konza Technology City has low progress and free port at Dongo Kundu did not take off as planned (Republic of Kenya, 2013).

\subsection{Statement of the Problem}

The Kenya Vision 2030 flagship projects were expected to take the lead in generating $10 \%$ economic growth in the country but they are currently threatened by inadequate source of funding, failure to link policy, planning and expenditure budgeting and poor expenditure outcomes at the macro, strategic and operational levels (World Bank, 2013). The projects are rarely completed within the anticipated time, poorly funded and some projects were agreed upon without reference to their cost to the exchequer, project appraisal systems and therefore attainment of the desired results is becoming difficult (KIPPRA, 2013). Despite cost-benefit analysis being credited to be an important technique for project appraisal, its application in the public sector continue to be elusive and therefore financial valuation of project costs and benefits is not clear and disclosure on the choice of the best project with net social benefits is scanty (World Bank, 2013).

It is indicated that, the financial troubles that face public projects is mainly attributable to planning process (Shah \& Hagen, 2007) appraisal criteria (Palmer, 2012), source of funds (Republic of Kenya, 2013) and management responsibility (Linder \& Foss 2013; Otiende, 2013). Therefore, without a clear financial framework that can be used to determine government expenditure on public projects, poor financial planning and inappropriate utilisation of public resources (Aruwa, 2010), militate against achieving targets set out in the Kenya Vision 2030. It is on this understanding that this study was conceptualized. The study evaluated the determinants of government expenditure on the public flagship projects in Kenya with a view of giving recommendation on ways to enhance sustainable development and increased economic growth as envisaged in Kenya Vision 2030.

\subsection{Objectives of the Study}

The general objective of the study was to evaluate the determinants of government expenditure on public flagship projects in Kenya. The specific objectives were:

i. To evaluate the influence of planning process on government expenditure on public flagship projects in Kenya.

ii. To evaluate the influence of source of funds on government expenditure on public flagship projects in Kenya.

iii. To evaluate the influence of management responsibility on government expenditure on public flagship projects in Kenya.

\subsection{Empirical Literature}

\subsubsection{Government Expenditure and Public Projects}

Plotnikova (2005), supported a claim that government spending is determined by public capital and source of its financing, political decision-making factors, infrastructure and control for spending culture, and budget composition spending rules. Kanano (2006) concluded that public expenditure is on the rise in Kenya yet the GDP is marginally increasing to sustain the public expenditure growth. From the findings, it is important that the government avoids over reliance on internal borrowing for financing public projects as this has detrimental effect on economic growth due to crowding out of the private sector.

IMF (2003) proposes that, government expenditure on public projects should be rooted in planning and economic theory and to do so, the projects should be directed centrally, perhaps by strategic plan. With a strategic plan government may identify and continuously evaluate long-range policy actions and projects that best create economic wealth commensurate with a national's strategic strengths. Aruwa (2010) using Quality Public Expenditure (QPE) framework recommended that, project expenditure should take account of the nature 
of expenditure with particular allocation of resources to identified productive areas. The reason for this is that project investments mainly increase productivity. It was however observed that, there is an ambiguity in the array of determinants used in analyzing and the method of measuring public project expenditure. Morgues (2012) showed that politicians, bureaucrats, interest groups, donors, institutional structures and economic governance environments affect the prioritization of public projects and investments.

\subsubsection{Planning Process and Project Expenditure}

Ndiritu (2007) revealed that the public sector ends up losing huge cash amounts due to lack of established operational plans and strategies to harmonize revenue collection and project expenditure. Hence, for valuable and effective expenditure decisions, there is need to set standards, act in a coordinated and harmonized manner to ensure that the expenditure objectives are achievable.Jones et al. (2009) argued that, in pursuing public projects and institutional interests, decision-makers are expected to act strategically as advocates, protecting public funds and request small increases from the previous year. According to Tulkoff et al. (2011), PBB is one of the key components of the expenditure planning, programming and budgeting systems reform. Programming would assist in administering efforts to efficiently accomplish goals and expenditure decisions would come up with financial estimates of resources needed by agencies to execute the plans.

Ottosson and Weissenrieder (2011) states that, project expenditure proposals should only be considered when they include a detailed disclosure of the expected operating costs, indicating how these are accommodated within existing resource envelopes and explanations om how existing fixed assets will be maintained. Pricewaterhouse Coopers (2012) suggested that government should consider budgetary process as a complex mix of environment, rules, practice, values, people and behaviours that is evolving and requires constant effort and work to drive forward reform and improve public expenditure management.

Qi and Mensah (2012) found out that implementation of PBB was negatively associated with total expenditures from consolidated fund, positively associated with total expenditures from other state funds and significantly negative for functional expenditures. According to World Bank (2013), the main objectives of the MTEF was to improve fiscal discipline; better inter- and intra-sectoral resource allocation through linking policy, planning and budgeting; greater budgetary predictability for line ministries; more efficient use of public resources through achieving performance and service delivery at least cost; greater credibility of budgetary decision making; greater political accountability for public expenditure outcomes through more legitimate decision making processes.

\subsubsection{Sources of Funds and Project Expenditure}

Shah (2005) affirmed that four major vehicles used for delivering government expenditure on projects are direct spending through departments and agencies as recorded in budgetary transactions; direct spending through funds that are not included in the budget; indirect spending through business enterprises it owns or controls; and spending programs delivered through tax system. According to International Monetary fund (2007) the possible sources of funding public projects include tax and property revenues, surpluses from current account, proceeds from borrowing, privatization proceed and support from development partners. Jacobs (2009) indicates that government expenditure on projects should be based on a consolidated budget approach, incorporating all revenues and expenditures, foreign-financed projects and extra-budgetary funds with investment activities.

Communication and Management Institute (2010) identified various problems associated with the revenue mobilization as: contradiction in the legal framework on revenue mobilization; poor revenue assignment provisions; lack of clarity on revenue bases and revenue sharing system between layers of government; weak incentive or structure for fiscal autonomy; unclear expenditure needs and financial impact of the transfer of tasks devolved to Local Governments; poor administrative capacity to assess revenue base and enforce the tax rules, political pressure to relax tax administration and revenue collection.

Chen (2011) showed that, major public projects with government funding in the form of direct government investment and capital injection, need approval documents including project appraisal, feasibility study and project design. Direct government funding is for public infrastructure projects which require a dominant role of the government. Capital injection can be used when projects may have significant impacts on the domestic economy and have other strategic importance. For projects that generate profit but need government funding to cover part or all of their investment, the State can carry out investment through purchase of stocks of the project and become the Government owner of shares.

Al-Zeaud (2011) while examining causal relationship between government revenues and project expenditure, showed that there was significant relationship between source of funds and public expenditure decisions. 
Al-Khulaifi (2012), Adnan and Jalil (2010), and Petanlar and Sadeghi (2012) confirmed findings by Hussain (2003), which determined the relationship between total government expenditures and total tax revenue and found that unidirectional effect from expenditure to revenue suggesting preference of controlling spending decisions to reduce tax revenue-expenditure deficit. From the Kenya Economic Survey, (Republic of Kenya, 2010) the main sources of public finance in Kenya are tax revenue (taxes on income profit and capital gains) and licensing fees which are received for paying for a permit or license.

\subsubsection{Management Responsibility and Project Expenditure}

According to Ablo and Reinikka (1998), development expenditure tracking surveys revealed that in Uganda only $30 \%$ of resources intended for non-salary education and health services actually reached the field level. The Government of Uganda's solution was to introduce conditional grants, paid by Ministry of Finance and Economic Planning to Districts, who are required to pass the full amount on to schools at a standard rate per pupil enrolled, with mechanisms to ensure transparency. Shapiro (2006) emphasizes that, where performance is taken into consideration in determining expenditure, it provides significant incentives for personnel, even if the pecuniary rewards are not significant. Shapiro (2006) recommends that, financial incentives may also be used to promote desirable institutional behaviour. For example, where agencies are allowed to carry-over efficiency savings at the end of the financial year they have a clear incentive to cut-costs since they are the beneficiaries of these savings. This is not the case where, as in most countries, savings have to be surrendered to the common fund. The logical conclusion of this approach is that government expenditure can be controlled by restricting inputs since appropriate targets and incentives have been put in place. The current study focused on specific performance considerations of fiscal discipline, transparency and accountability as opposed to Shapiro (2006) findings that were of general approach.

Since decision makers may have a better understanding of citizens' needs than central agencies and politicians, expenditure targeting can allow managers to improve on the decisions they make. This has been the approach favoured under New Public Management reforms (Strehl, Reisinger, \& Kalatschan, 2007). Strehl, Reisinger, \& Kalatschan (2007) findings indicates that, effective expenditure management and accountability may not exist in many developing countries. In fact, contracts may not be enforced; patron-client relationships may prevail, making it difficult to associate performance or non-performance with expenditure budgetary allocations. Fozzard and Foster (2001) concluded that, managerial approach implies a wider institutional scope than what has traditionally been the case, extending beyond the core functions of Ministries of Finance to include expenditure management at agency level, down to the point where clients and citizens access public services. At the same time, public expenditure management has also moved upstream, recognizing that expenditures are policy decisions and that system performance can only be assessed in relation to policy goals. In tandem with the new focus on performance, public expenditure decision and management systems have also come to be viewed as a key instrument of governance. This study reiterated the requirements that public expenditure decisions should not only be transparent and accountable, but also involve citizens in decision making.

Public finance has been re-focusing requirement to produce annual statements of intent that emphasize a strategic outcomes framework (Webber, 2004). An explicit consequence of this focus has been less reliance on the previous, narrower, output-based planning. This more explicit focus on outcomes in the planning process is required to be reflected and reinforced by parallel adjustments in post-performance reporting. It was shown that it is imperative for public sector experts to embrace shifting budget focus from accounting for input to output; devising performance budget measures and moving towards more appropriate accounting standards, and developing were underpinning instruments in ensuring transparency and accountability. This status of affairs was referred to as the second generation of fiscal rules and frameworks, an innovation where transparency and accountability are essential elements. The credibility of fiscal rules and objectives is strengthened if such measures are accompanied by enhanced fiscal transparency, as this openness complements rules-based approach in three ways: by removing any tendency to be nontransparent to meet rules; by facilitating judgments of actual fiscal performance against rules, which makes transparency an essential requirement for rules to be effective; and by allowing justifiable flexibility in the application of rules. Webber (2004) insists the need for transparency and accountability in project expenditure which is an essential element of the present study. However, they failed to show how ensuring transparency and accountability determines project expenditure in the public sector, which is what the present study strived to achieve.

Rauchhaus (2009) shows that, while it is possible to improve credibility of government expenditure decisions by improving design of budget procedures and institutions, this fails to resolve the underlying problem: agents act against the principals' interests because their interests diverge. One means of resolving this is through performance management systems. Targets should be set for public agencies and staff, linked to Government's 
policy goals, and mechanisms should be established to monitor projects against these measures. Jones et al (2009), gave an insight into the nature of project expenditure budgeting, its intellectual justification, antecedents, and present and future use in the public sector. It was observed that, it is not a straight forward task and cannot exhaustively be explained how responsibility expenditure decision is used and how it works. Responsible expenditure decisions make sense only as a part of a framework of structural, procedural, and monitoring and reporting relationships. At the same time, responsibility budgeting and accounting, or their functional equivalents, make an essential contribution to the efficacy of this broader framework of relationships. Jones et al. (2009) asserts that the efficacy of administrative relationships depends upon their congruity with each other as well as with the purposes and products of the entity in question and the productive and information processing technologies available to it. The present study, based on these findings investigated management responsibility as a determinant of government expenditure on public projects.

\subsection{Conceptual Framework}

The study was conceptualized that, government expenditure on public flagship project in Kenya is determined by planning process, source of funds and management responsibility which are independent variables while government expenditure on public flagship projects was the dependent variable. However, the intervening variable which may affect the government expenditure on public flagship project but is controlled elsewhere included in the study is inflation as a macro-economic variable.

Independent Variables
\begin{tabular}{|cl|}
\hline Planning process \\
- & Strategic plans \\
- & PBB \\
- & MTEF \\
\hline Source of Funds \\
- & Exchequer \\
- & Donor support \\
- & PPP financing \\
\hline Management Responsibility \\
- & Accountability \\
- & Transparency \\
- & Fiscal discipline \\
\hline
\end{tabular}

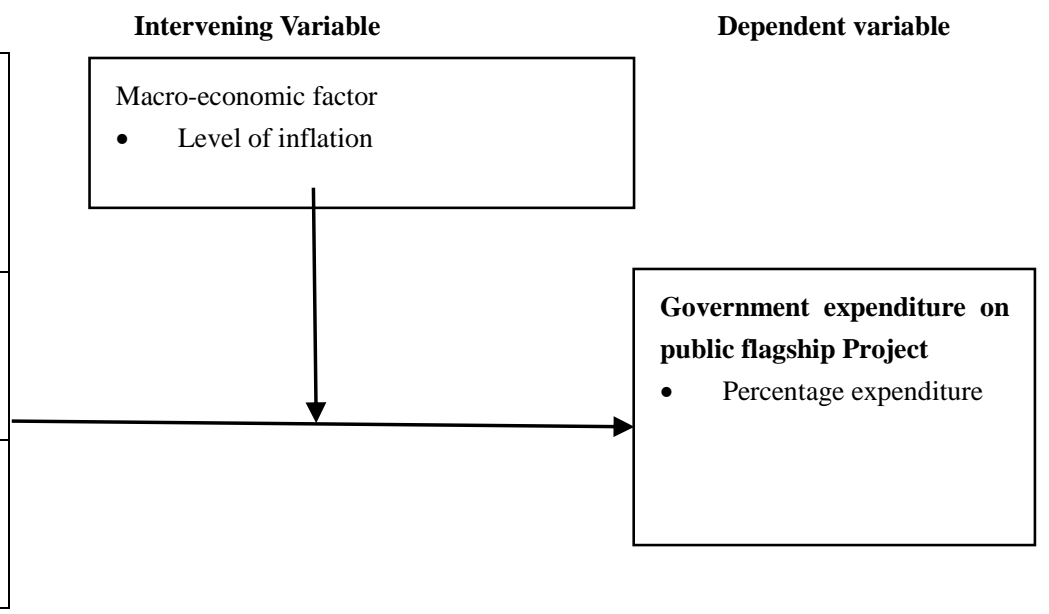

Figure 1. Conceptual framework

Source: Adopted and modified from Shah and Von Hagen, (2007).

The conceptual framework in Fig 1 above consists of the independent variables on the left and dependent variable on the right. The planning process was evaluated based on four indicators which were strategic plans, MTEF, PBB and incremental costing. The source of funds components were exchequer (funds availed by the National Treasury), development partners and public-private partnerships. The indicators for management responsibility were fiscal discipline, transparency and accountability. Government expenditure on the flagship projects was determined as a percentage between actual expenditure against the planned cost outlay for the projects.

\section{Methodology}

\subsection{Study Design and Research Philosophy}

This study used descriptive survey design since it provides insights into the research problem by describing the variables of interest. It was used for defining, estimating and evaluating the influence of independent variables on government expenditure on public flagship projects in Kenya. This helped in providing useful information to meet the research objectives. The study employed and adopted positivist paradigm since Weaver and Olson (2006) indicate that government expenditure on public flagship projects is guided by rules of logic, measurement, absolute principles and prediction.

The study used multiple regression model which measured the effect of predictor variables on actual government expenditure on flagship projects. F-test was used to determine whether the relationship can be generalized to the 
population represented by the sample while a t-test was used to evaluate the significance of correlation coefficients of individual relationship on the dependent variable.

\subsection{Target Population, Sampling Design and Data Collection Procedures}

The overarching aim of the study was to evaluate determinants influencing government expenditure on public flagship projects in Kenya that had been planned for implementation during the period 2008-2012 within the Kenya Vision 2030 First Medium Plan (Republic of Kenya, 2008). The target population were the 348 projects earmarked for implementation to cover the four (4) areas of the Kenya Vision 2030 First Medium Plan flagship projects.

The 348 projects were distributed to cover four areas of national transformation, economic, social and political pillar. The projects for the national transformation were 134 projects representing $38.5 \%$ of the total 348 projects while economic pillar with 81 projects accounted for 23.3 percent. The social and political pillar was 113 and 20 projects representing $32.5 \%$ and $5.7 \%$ respectively. The unit of analysis was public flagship projects which been planned for implementation in the period 2008-2012.

The study used stratified simple random sampling. This was occasioned so as to avoid the risk of selecting the sample projects from one class of the flagship projects. A random sample from each stratum (class) of the flagship projects was taken in a number proportional to the stratum's size when compared to the population. These subsets of the strata were then pooled to form random sample units. The selected 96 sample size of projects was distributed among the four classes of public flagship projects of First Medium Plan. The number of projects sampled from national transformation was 37 projects representing $38.5 \%$ of the total of the 96 sample size while those sampled from economic pillar were 22 projects accounting for 22.9 percent. A total of 31 and 6 were sampled from the social and political pillar projects representing $32.3 \%$ and $6.3 \%$ respectively.

Data was collected from primary sources using questionnaires with both open and closed ended questions. The questions were standardized to allow the respondents to reply to the same questions in a defined manner and open ended questions used to give the respondents freedom of response and encourage them to offer explanation. The use of questionnaires enabled collection of adequate information in a relatively cost effective way and the results of the questionnaires quantified.

\section{Results and Findings}

Significance tests at 5 percent level were carried out to establish the significance of the independent variable in determining the dependent.The decision on the level of the correlation coefficient was considered to be statistically significant when the computed t-value was greater than the critical value of t-distribution at 0.05 level of significance. The analysis used a two tail test at $5 \%$ level of significance. Table 1 below shows, the influence of the individual independent variable in determining government expenditure (EP) on the four (4) categories of flagship projects.

Table 1. Influence of individual independent variable in the regression analysis

\begin{tabular}{|c|c|c|c|c|}
\hline \multirow{2}{*}{$\begin{array}{c}\text { Type of Project } \\
\text { Category }\end{array}$} & \multirow[t]{2}{*}{ Inferential Statistics } & \multicolumn{3}{|c|}{ Independent Variable } \\
\hline & & Planning Process (PP) & Sources of Funds (SF) & Management Responsibility (MR) \\
\hline Foundation for & Pearson correlation coefficient & 0.752 & 0.543 & 0.501 \\
\hline National & Significance level & 0.000 & 0.016 & 0.029 \\
\hline \multirow[t]{2}{*}{ Transformation } & $\mathrm{N}$ & 19 & 19 & 19 \\
\hline & Pearson correlation coefficient & 0.683 & 0.898 & 0.302 \\
\hline \multirow[t]{3}{*}{ Economic Pillar } & Significance level & 0.111 & 0.035 & 0.275 \\
\hline & $\mathrm{N}$ & 16 & 16 & 16 \\
\hline & Pearson correlation coefficient & 0.537 & 0.913 & 0.692 \\
\hline \multirow[t]{3}{*}{ Political Pillar } & Significance level & 0.3720 & -0.068 & -0.244 \\
\hline & $\mathrm{N}$ & 5 & 5 & 5 \\
\hline & Pearson Correlation coefficient & 0.631 & 0.509 & 0.476 \\
\hline \multirow[t]{2}{*}{ Social Pillar } & Significance level & 0.000 & 0.007 & 0.012 \\
\hline & $\mathrm{N}$ & 27 & 27 & 27 \\
\hline
\end{tabular}

Note. $\mathrm{N}$ represents number of responses.

Source: Research Data (2015).

From table 1 above, the study shows that, planning process had a positive coefficient of correlation of 0.752 in 
determining government expenditure on flagship projects of the foundations for national transformation whereas its influence on projects from economic pillar was established at 0.683 . Similarly, the planning process had a positive influence of 0.537 and 0.631 on political and social pillar projects respectively. The statistical significance of these coefficients shows that, planning process had student t-value of 0.0 .00 for foundation for national transformation and social pillar projects. since this significance level value of .0 .00 is less than $0.05(\mathrm{p}<0.05)$, it can be concluded that planning process had influence in determining government expenditure on public flagship project derived from foundation for national development and social pillar flagship projects in Kenya. In the same vein, significance level for economic $(0.111)$ and political $(0.372)$ are more than $0.05(\mathrm{p}<0.05)$ then at $5 \%$ level of significance, it is conclusive that planning process alone had no influence in determining government expenditure on public flagship project in Kenya.

In establishing the significance of source of funds table 1 above shows that source of funds has coefficient value of 0.543 when regressed on foundations for national transformation, 0.898 on economic pillar, 0.913 on political and 0.509 on social pillar. This shows that source of funds moves in the same positive direction with government expenditure on flagship projects. The test of significance for these coefficients is that source funds had significance level on foundation projects $(0.016<0.05)$, economic pillar $(0.035)$ and social pillar $(0.007<0.05)$ while it had no significance in determining political pillar projects $(0.068>0.05)$

The results from table 1 above show that management responsibility had coefficient value of 0.501 when regressed on foundations for national transformation, 0.275 on economic pillar, 0.302 on political and 0.476 on social pillar. This shows that management responsibility moves in the same positive direction with government expenditure on flagship projects. The test of significance for these coefficients is that management responsibility had significance level on foundation projects $(0.029<0.05)$, social pillar $(0.012<0.05)$ while it had no significance in determining government expenditure on economic pillar projects $(0.275>0.05)$ and political pillar $(0.244>0.05)$. The overall influence of the independent variable is shown in table 2 below.

Table 2. The overall regression analysis

\begin{tabular}{lccccccc}
\hline Variable & \multicolumn{2}{c}{ Unstandardized values } & \multicolumn{2}{c}{ Standardized values } & \multicolumn{2}{c}{ Collinearity Statistics } \\
\cline { 2 - 8 } & Coefficient (Beta) & Std error & Beta & Student t-value & Significance P-Value & Tolerance & VIF \\
\hline Constant & 86.97 & 42.615 & & 2.041 & 0.045 & & \\
Planning Process & 3.937 & 11.078 & 0.056 & 0.355 & 0.023 & 0.558 & 1.791 \\
Sources of Funds & 4.504 & 8.814 & 0.07 & 0.511 & 0.011 & 0.731 & 1.367 \\
Management Responsibility & 28.588 & 11.075 & 0.428 & 2.581 & 0.012 & 0.501 & 1.995 \\
\hline
\end{tabular}

Source: Research data (2015).

From table 2 above, the study shows that, planning process (PP), sources of funds (SF) and management responsibility (MR) have positive coefficient of correlation of 3.937, 4.504 and 28.588 respectively. The test for statistical significance of these coefficients shows that, planning process had student $t$-value of 0.355 and $\mathrm{p}$-value of 0.023 . Since 0.023 is less than $0.05(\mathrm{p}<0.05)$ then at $5 \%$ level of significance $(\alpha=0.05)$, there exists enough evidence to conclude that planning process is a predictor of government expenditure on public flagship project in Kenya.

In establishing the significance of source of funds table 2 above shows that source of funds has t-value of 0.511 and p-value of 0.011 and therefore, there exists sufficient indication to conclude that sources of funds had an influence in determining government expenditure on public flagship project in Kenya. Similarly, management responsibility has student $\mathrm{t}$-value of 2.581 and $\mathrm{p}$-value $=0.012$. Since $0.012<0.05$ there exists enough evidence to conclude that the management responsibility is useful as a predictor of government expenditure on public flagship project in Kenya. Consequently, these results show that all the coefficients are statistically significant and based on the data available there is sufficient evidence that there is a positive influence relationship between government expenditure on flagship projects and the independent variables.

Using the overall coefficients from table 2 above, the estimated equation is derived to be: $E P=86.990+3.937 P P+28.588 M R+4.504 S F$. This shows that all the independent variables; planning process, source of funds and management responsibility had positive coefficients, which showed that they had direct influence on government expenditure on flagship project. This means that an improvement in; planning process, management responsibility and source of funds will lead to improvement in government expenditure on public flagship project and vice versa. Hence, the interpretation of the observed correlation is that government 
expenditure on public flagship projects is significantly determined by the planning process, source of funds and management responsibility. Management responsibility stands out with more influence at factor of 28.588 such that an improvement in management responsibility by a factor of one (1) is likely to improve government expenditure on public flagship by 28.6 percent. A potential policy implication might be that it would be desirable to encourage governments to improve on fiscal discipline, financial transparence as well as financial accountability when designing expenditure on the public flagship projects.

Further, estimation of the model shows that planning process influences government expenditure on public flagship projects at factor of 3.9 which implies that enhancement of planning process by a factor of one (1) is likely to improve government expenditure on public flagship projects by 3.9 percent. An underlying strategy consequence is that it would be necessary for governments to improve strategic planning, programme based budgeting and deepening use of medium term expenditure in deciding expenditure on flagship projects of the Kenya Vision 2030 blue-print. In fact this direction is bolstered by the Section 38 of Public Finance Management Act, 2012 Laws of Kenya which requires the National Treasury prepare expenditure proposals that are based on programmes within a given medium term expenditure framework.

It can be seen from the model, source of funds influence government expenditure on public flagship projects by 4.5 times which implies that increasing source of funds by 1 unit will improve government expenditure on public flagship project by 4.5 percent. The source of funds analysed had three components of exchequer, development partners and PPP arrangements. This result connects well with World Bank (2011) that has shown that governments are increasingly relying on Public-Private Partnerships as additional source of financing public sector projects. Nevertheless, governments will still have to make arrangements for direct financing and fiscal support to cover project cost such as guarantees, in-kind grants, and tax-breaks.

The findings indicate that, to achieve the desired outcomes of Kenya Vision 2030, there is need to bolster public expenditure management. This assertion is in line with Musgrave (1959) on public finance theory which asserted that, government expenditure should be devoted to increasing aggregate demand, economic efficiency, and redistribution of income. Further the model from the study attempts to extend Oates (2007) and Obioma and Ozughalu (2010) who in a nutshell postulated that, public expenditure is a vehicle for efficient allocation of resources. They argued that public expenditure greatly depends on revenue collection and economic development results expected. However, in addition to revenue sources this study indicates that government expenditure is also determined by planning process and management responsibility.

In addition, government expenditure on projects still remains key in realising the desired budget outcomes. The findings therefore affirms that budget theories enunciated by Pyhrr (1970), Schick (1990) and World Bank (1998a: 32) are still applicable in designing government expenditure on public flagship projects. The key insight from the findings is the support to the budget theory. However, deriving from theoretical framework public sector experts need to provide the linking framework that allows expenditures to be driven by policy priorities and disciplined by budget realities (World Bank, 1998a: 32). If the problem is that policy making, planning, and budgeting are disconnected, then a potential solution is an MTEF. MTEF has increasingly come to be regarded as a central element of public expenditure management reform programs as stated by World Bank (2013). The framework allows expenditures to be driven by policy priorities and fiscal discipline based on budget realities. The model developed from the study shows that management responsibility has significant influence which clearly emphasises the role of principal-agent theory in designing government expenditure as elucidated by Levacic (2009) and McKie et al. (2010). The results also stress the tenets of principal-agent theory that advocates for accountability and transparency of decision makers, who should be compelled to choose projects that benefit the citizens.

\section{Conclusion and Policy Recommendations}

\subsection{Conclusion}

The results of the model showed planning process which was evaluated based on PBB, MTEF and incremental costing had a significantly positive influence in determining government expenditure on public flagship project in Kenya. Thus, an improvement in planning process by a factor of one is likely to positively influence government expenditure on public flagship projects.

Further, source of funds positively influence government expenditure on public flagship projects which connects well with World Bank (2011) indication that governments need to widen source of funding. It was found out that most of the projects earmarked for PPP arrangements did not take-off as planned. While arrangements for PPP could attract successful private capital this may need a critical analysis for it to yield the desired outcomes. 
In addition, management responsibility had a positive influence in determining government expenditure on public flagship projects such that an improvement in management responsibility is likely to improve government expenditure on public flagship projects.

\subsection{Policy Recommendations}

From the study, it is recommended that all public entities should strengthen and improve application of the planning process in determining government expenditure on flagship projects. This should entail deepening the use of MTEF within a PBB framework. The use of PBB will improve cost-efficiency, effective management of project expenditure outlays, increasing visibility into how government policies translate into spending and making systematic use of performance information while MTEF provides a platform for linking public policy, planning and expenditure budgets on the projects.

In addition, it is recommended that the National Treasury should increase and scale-up available resources for financing public flagship projects. In doing so, there is need to consider PPP as a potential source of funding public projects. Further, the Government should encourage public entities to improve, strengthen and enforce management responsibility when planning expenditure on public flagship projects. The management responsibility improvement should focus on fiscal discipline, financial transparence as well as financial accountability when designing expenditure on public flagship projects.

For the purpose of improving public finance practice, the public sector expenditure planners should ensure that all expenditure outlays are linked to specific project performance results. The use of performance results should form part of the basis of holding agencies accountable for performance and ensure that performance results determine budget allocations. In addition, public sector managers should strengthen expenditure planning to ensure that expected outputs are specified in the budget or related documents to enable government to compare set targets and actual results.

The two suggestions for further research can be to explore the impact of project characteristics on the choice of PPP financing model; and the impact of fiscal decentralization on financing public projects in light of devolved systems of governance.

\section{References}

Abdullah, H., \& Maamor, S. (2010). Relationship between National Product and Malaysian Government Development Expenditure: Wagner's Law Validity Application. International Journal of Business and Management, 1(5), 88-97. https://doi.org/10.5539/ijbm.v5n1p88

Ablo, E., \& Reinikka, R. (1998). Do Budgets Really Matter? Evidence from Public Spending on Education and Health in Uganda. World Bank Policy Research Working Paper No. 1926. https://doi.org/10.1596/1813-9450-1926

Adnan, Q. M., \& Jalil, A. (2010). Revenue and expenditure nexus: A case study of Romania. Romanian Journal of Fiscal Policy (RJFP), 1(1), 22-28.

Al-Khulaifi, A. S. (2012). The Relationship between Government Revenue and Expenditure in Qatar: A Cointegration and Causality Investigation. International Journal of Economics and Finance, 4(9), 142-148. https://doi.org/10.5539/ijef.v4n9p142

Al-Zeaud, H. A. (2011). Government Revenues and Expenditures: Causality Tests for Jordan. Interdisciplinary Journal of Contemporary Research in Business, 4(7).

Aruwa, S. A. A. (2010). The Quality of Public Expenditures in Nigeria. Kaduna: Nigerian Defence Academy.

Bowie, E., \& Norman, E. (2004). Ethics and agency theory: An introduction. New York: Oxford University Press.

Communication and Management Institute. (2010). Report on A Study to Identify Sources of Revenue, Revenue Mobilization Capacity and Expenditure Needs in Mountainous (Himali) Districts. Maharajgunj, Kathmandu: Communication and Management Institute Publishers Ltd,

European Union. (2014). Digital Agenda for Europe: A Europe 2020 Initiative.

Ferejohn, J. (2009). Incumbent Performance and Electoral Control. Public Choice, 50, 5-25. https://doi.org/10.1007/BF00124924

Fozzard, A., \& Foster, M. (2001). Changing Approaches to Public Expenditure Management in Low-income Aid Dependent Countries. Tokyo: United Nations University Press. 
Gailmard, S., \& Patty, J. (2007). Slackers and Zealots: Civil Service, Bureaucratic Discretion, and Policy $\begin{array}{lllll}\text { Expertise. American Journal of Political } & \text { Science, }\end{array}$ https://doi.org/10.1111/j.1540-5907.2007.00286.x

Good, D. A. (2011). Still budgeting by muddling through: Why disjointed incrementalism lasts. Policy and Society, 30, 41-51.

Government Finance Officers Association. (2011). Zero-Base Budgeting Modern Experiences and Current Perspectives. Chicago, IL: Government Finance Officers Association.

HM Treasury. (2013). The Green Book Appraisal and Evaluation in Central Government, Treasury guidance. The Stationery Office, London.

Hussain, M. H. (2003). On the Causal Relationship between Government Expenditure and Tax Revenue in Pakistan. The Lahore Journal of Economics, 9(2), 105-120.

Institute of Economic Affairs. (2013). Budget 2013/14: The Onset of the Devolved Government and the Hurdles Ahead, Nairobi.

International Monetary Fund. (2003). Performance Budgeting: Linking Funding and Results. Palgrave: Washington, D.C Macmillan Publishers.

International Monetary Fund. (2010). World Economic Outlook April 2010. Re-balancing Growth. Washington, D.C: International Monetary Fund Publication Services. https://doi.org/10.5089/9781589069565.081

Jacobs, D. F. (2009). Public Financial Management Technical Guidance Note No. 8: Capital Expenditures and the Budget. Retrieved from http://blog-pfm.imf.org/files/capital-expenditures-and-the-budget.pdf

Jin, J., \& Zou, H. (2005). Fiscal Decentralization, Revenue and Expenditure.

Jones, B. D., Baumgartner, F. R., Breunig, C., Wiezien, C., Soroka, S., Foucault, M., et al. (2009). A general empirical law of public budgets: A comparative analysis. American Journal of Political Science, 53(4), 855-873. https://doi.org/10.1111/j.1540-5907.2009.00405.x

Kanano, A. G. (2006). Determinants of public expenditure growth in Kenya. University of Nairobi Digital Repository

Kenya Institute of Public Policy Research and Analysis. (2013). Kenya Economic Report 2013, Nairobi.

Labonte, M. (2010). The Size and Role of Government: Economic Issues. Congressional Research Service, Washington, DC:

Levacic, R. (2009). Teacher Incentives and Performance: An Application of Principal-Agent Theory. Oxford Development Studies, 37(1). https://doi.org/10.1080/13600810802660844

Linder, S., \& Foss, N. J. (April 23, 2013). Agency Theory. https://doi.org/10.2139/ssrn.2255895

McKie, K., \& Walle, N. (2010). Toward an Accountable Budget Process in Sub-Saharan Africa: Problems and Prospects. Social Research, 77(4), 1281-1310.

Morgues. (2013). What Determines Public Expenditure Allocations? A Review of Theories, and Implications for Agricultural Public Investment. International Food Policy Research Institute, Washington, DC. https://doi.org/10.2139/ssrn.2198472

Musgrave, R. A. (1959). Public Finance in theory and Practice. New York: Mc-Graw Hill.

Ndiritu, G. M. (2007). Effectiveness of Cash Budgeting In Public Institutions: A Case Study of Telkom Kenya Ltd. Unpublished Masters Project, University of Nairobi, Nairobi.

Otiende, C. O. (2013). Factors Affecting Implementation of the Kenya Vision 2030 Strategy in Public Sector: Kenyatta International Conference Centre. Unpublished Research, Masters of Business Administration (Strategic Management), Nairobi: Kenyatta University.

Ottosson, E., \& Weissenrieder, F. (2011). Linking Capital Allocation to Individual Capital Expenditure Decisions. Stockholm: CVA Development AB.

Palmer, D. A. (2012). Financial Management Development. Retrieved from http://www.FinancialManagementDevelopment.com

Petanlar, S. K., \& Sadeghi, S. (2012). Relationship between Government Spending and Revenue: Evidence from Oil Exporting Countries. International Journal of Economics and Management Engineering (IJEME), 2(2), 33-35. 
Plotnikova, M. (2005). The Effect of a Capital Budget on Capital Spending in the United States of America. Unpublished Master Thesis, Blacksburg, Virginia Polytechnic Institute and State University.

PricewaterhouseCoopers. (2012). Good budgetary processes: Comparators Case studies from the public and private sector. National Audit Office, London.

Pyhrr, P. A. (1970). Zero-Based Budgeting. Havard Business Review, 48(6), 111-121.

Qi, Y., \& Mensah, Y. M. (2012). An Empirical Analysis of the Effect of Performance-Based Budgeting on State Government Expenditures. China University of Petroleum- Beijing. https://doi.org/10.2139/ssrn.1970079

Rauchhaus, R. (2009). Principal-agent problems in humanitarian intervention: Moral hazards, adverse selection, and the commitment dilemma. International Studies Quarterly, 53(4), 871-84. https://doi.org/10.1111/j.1468-2478.2009.00560.x

Republic of Kenya. (2008). Vision 2030 First Medium Term Plan. A Globally Competitive and Prosperous Kenya, 2008-2012. Government Printer Nairobi.

Republic of Kenya. (2010). Kenya Economic Survey. Nairobi: Government Printer.

Republic of Kenya. (2011). Programme Based Budgeting Manual. Ministry of Finance Nairobi.

Republic of Kenya. (2011). Second Annual Progress Report on the Implementation of the First Medium Term Plan 2008-2012) Kenya Vision 2030. Ministry of State for Planning, National Development and Vision 2030. Nairobi, Government of Kenya.

Republic of Kenya. (2013a). Eye on Budget, Spending for Results: Comprehensive Public Expenditure Review. Ministry of Devolution and Planning, Nairobi.

Republic of Kenya. (2013b). The Strategy for Public Finance Management Reforms in Kenya (2013-2018). National Treasury, Nairobi.

Schick, A. (1988). An Inquiry into the Possibility of a Budget Theory. In I. S. Rubin (Ed.), New Directions in Budget Theory (pp. 56-69). Washington, DC.

Sean, G. (2012). Accountability and Principal-Agent Models, Oxford Handbook of Public Accountability. Oxford: Oxford University Press.

Shah, A., \& Von, H. J. (2007). Budgeting and Budgetary Institutions, Herndon, VA, USA: World Bank. https://doi.org/10.1596/978-0-8213-6939-5

Shapiro, S. (2006). Agency Theory: Annual Review of Sociology. American Bar Foundation, Chicago, Illinois.

Strehl, F., Reisinger, \& Kalatschan. (2007). Funding systems and their effects on higher education system. OECD Education Working Papers.

Tulkoff, M. L., Gordon, C. V., Dubin, R. D., \& Hinkle,W. P. (2011). Planning, Programming, and Budgeting System. Institute for Defense Analyses Alexandria, Virginia

United Nations Industrial Development Organization [UNIDO]. (2008). Public goods for economic development. Austria: UNIDO Publication.

Weaver, K., \& Olson, J. K. (2006). Understanding paradigms used for nursing research. Journal of Advanced Nursing, 53, 459-69. https://doi.org/10.1111/j.1365-2648.2006.03740.x

Webber, D. (2004). Managing The Public's Money: From Outputs To Outcomes - And Beyond. OECD Journal on Budgeting, 4(2). https://doi.org/10.1787/budget-v4-art10-en

Wenting, C. (2011). A review on the project appraisal processes for major public investments in China. Faculty of Engineering Science and Technology, Norwegian University of Science and Technology.

World Bank. (1998). Public Expenditure Management Handbook. Esp. Ch. 3, "Linking Policy, Planning, and Budgeting in a Medium Term Framework".

World Bank. (2013). The Kenya Economic Update (8th ed.). Washington D.C.

\section{Copyrights}

Copyright for this article is retained by the author(s), with first publication rights granted to the journal.

This is an open-access article distributed under the terms and conditions of the Creative Commons Attribution license (http://creativecommons.org/licenses/by/4.0/). 